\title{
Alligation Alternate and the Composition of Medicines: Arithmetic and Medicine in Early Modern England
}

\begin{abstract}
ALVAN BREGMAN*
Practical mathematics in the early modern period was applied to such fields as astronomy and navigation; cartography and surveying; engineering and military arts, including gunnery; and especially banking and mercantile trade. Those who have written about practical mathematics make no mention of medical applications in their surveys, although there were many cases where physicians set up as mathematical practitioners. ${ }^{1}$ This article examines medical applications found in practical mathematical literature up to the end of the seventeenth century in England.

While instruction in the medical applications of mathematics are scarcely to be found in earlier English publications, we shall see that a sudden minor outburst occurred in the 1650 s, when three separate arithmetics appeared with chapters on "the composition of medicines". These chapters were each associated with a mathematical operation called "alligation", a term which means "tying together". There are two main types of alligation: "alligation medial" for simple problems and "alligation alternate" for use when varied quantities and elements are to be mixed. It was the technique called alligation alternate that was adapted specifically to the composition of medicines in these arithmetics.

Alligation was a relatively advanced arithmetical operation, presupposing a knowledge of the rules of proportion. As such, alligation was usually presented near the end of arithmetical texts. Most commonly the examples used to explain alligation involved grains, metals, wines or spices. A typical use of alligation alternate would be to determine the appropriate quantities to mix of various elements each having a different price in order to concoct a mixture destined to sell at a desired unit price. For example, say you are a grocer and you have ample quantities of wheat, rye, barley and oats, which sell respectively for
\end{abstract}

\footnotetext{
(C) Alvan Bregman 2005

*Alvan Bregman, BA (Trent), MA (McMaster), PhD, MLS (Toronto), Rare Book Collections Librarian, University of Illinois at Urbana-Champaign, University Library, 1408 W. Gregory Drive, Urbana, IL 61801; abregman@uiuc.edu.

The author wishes to thank the Wellcome Trust and the UIUC Campus Research Board for Travel Awards related to this research. Thanks also go to the faculty and staff of the Wellcome Trust Centre for the History of Medicine at UCL and of the Wellcome Library for their unfailing courtesy during the author's visit as a Research Associate, and to Professor Dan Grayson, UIUC Department of Mathematics, for his advice on mathematical questions.
}

To facilitate the identification of the various editions discussed in this paper, the numbers assigned to them in the following catalogues have been included: English Short-Title Catalogue: (ESTC); the Short-Title Catalogue of English Books printed in England, Scotland, and Ireland, and of English books printed abroad, 1475-1640: (STC); and the Short-Title Catalogue of Books printed in England, Scotland, Ireland, Wales and British America, and of English books printed in other countries, 1641-1700: (Wing).

\footnotetext{
${ }^{1}$ See, for example, E G R Taylor, The mathematical practitioners of Tudor and Stuart England, Cambridge, for the Institute of Navigation at the University Press, 1967, passim; J A Bennett, 'The challenge of practical mathematics', in Stephen Pumfrey, Paolo L Rossi and
} 
Alvan Bregman

\begin{tabular}{|c|l|l|l|}
\hline $\begin{array}{l}\text { Desired price } \\
\text { per bushel of } \\
\text { mixture }\end{array}$ & $\begin{array}{l}\text { Elements } \\
\text { to be } \\
\text { mixed }\end{array}$ & $\begin{array}{l}\text { Price per } \\
\text { bushel }\end{array}$ & $\begin{array}{l}\text { Difference in } \\
\text { price of alternate } \\
\text { elements to } \\
\text { desired price }\end{array}$ \\
\hline \multirow{2}{*}{16} & Wheat & {$\left[\begin{array}{l}28 \\
{\left[\begin{array}{l}20 \\
{[16-10=] 6} \\
{[16-14=] 2}\end{array}\right.} \\
\end{array}\right.$} & Barley \\
& Oats & {$[20-16=] 4$} \\
10 & {$[28-16=] 12$} \\
\hline
\end{tabular}

Figure 1: Calculation using alligation alternate.

28, 20, 14 and 10 pence a bushel. For whatever reason, you wish to sell a mixture of these grains at 16 pence a bushel. What quantities of each grain should you mix? The solution of the problem, using alligation alternate, looks like Figure 1.

The desired price is set to the left of the list of the elements to be mixed, ordered from highest to lowest in terms of their known price per unit. In this simple example, two of the elements happen to be priced higher and two are priced lower than the desired price of the mixture. The calculation first involves linking-i.e., "alligating"pairs of elements in the list, namely, one element priced higher and one element priced lower than the desired price per unit. In our example, wheat and oats are linked, wheat being more expensive per unit and oats being less expensive per unit than the desired price of the final mixture. The difference per bushel between the desired price (16 pence) and the price of the less expensive member of the linked pair, i.e., oats (10 pence), is calculated and the result (6 pence) is placed in a column to the right of wheat, the more expensive member of the linked pair. Then the difference per bushel between the more expensive member of the linked pair, i.e., wheat ( 28 pence) and the desired price (16 pence) is calculated and the result (12 pence) is placed in a column to the right of oats, the less expensive member of the linked pair. The same operation is carried out for rye and barley, the other linked pair in the problem. Using alligation alternate, we have determined that if 6 bushels of wheat, 2 bushels of rye, 4 bushels of barley and 12 bushels of oats are mixed together, the resulting mixture can be sold at 16 pence per bushel. $^{2}$

Jonas Moore was the first practical mathematician in England to promote alligation alternate systematically to a medical application. His Arithmetick, ${ }^{3}$ published in early 1650 , featured not only a chapter on alligation (from which the example above was

Maurice Slawinski (eds), Science, culture and popular belief in Renaissance Europe, Manchester and New York, Manchester University Press, 1991, pp. 176-90.

\footnotetext{
${ }^{2}$ Note that this is only one of many possible answers that will solve the problem correctly using alligation alternate.

${ }^{3}$ Jonas Moore, Moores arithmetick, London, printed by Thomas Harper for Nathaniel Brookes, 1650 (Wing M2563). See note 42 below.
} 


\section{Alligation Alternate and the Composition of Medicines}

taken), but a related chapter on 'The Composition of Medicines', and the novel subject of the composition of medicines was highlighted on the title-page itself:

MOORES ARITHMETICK: Discovering the secrets of that Art in Numbers and Species. In two Bookes. The first, teaching (by Precept and Example) the ordinary Operations in Numbers whole and broken; the Rules of Practise, Interest, and performed [sic] in a more facile manner by Decimalls, then hitherto hath been published; the excellency, and new practise and use of the Logarithmes, Nepayres bones, together with many Propositions, touching the Quantities, Qualities, Resultments and Rules of Medicines.... Fitted to the meanest Capacity, and published for the generall good of this Kingdome. [Emphasis added.]

In his text, Moore said that his propositions on the application of alligation to medicine were "never to my knowledge written on before". ${ }^{4}$ Moore's biographer, Frances Willmoth says, to the contrary, that "the medical applications of alligation were already well known". 5 Regardless of the extent to which they may have been generally known, we shall see that these applications had not been spelled out, at least in English, just as Moore claimed. Moreover, by showing how to control the composition of medicines, Moore was offering to explain what was an uncertain subject.

Compound remedies had an ambiguous place in early modern medicine, as Andrew Wear has shown in his lucid and comprehensive study of the period. ${ }^{6}$ On the one hand, compounds were recommended by physicians and other medical practitioners and sought after by the public; on the other, they were criticized as being expensive, complicated to make, and suspect, in that "they literally hid the true virtues of simples". 7 According to Wear,

[I]t was difficult to see how complex compounds could be justified in terms of rational and methodical medicine for, as William Harrison wrote, "the greater number of simples that go unto any compound medicine, the greater confusion is found therein because the qualities and operations of very few of the particulars are thoroughly known". Often remedies would conflict with one another in terms of their qualitative powers, and it would be practically impossible to adjust the whole composition so that it was appropriate to the disease and to the patient's circumstances. ${ }^{8}$

The situation had not much changed by the Interregnum, and Wear cites James Primrose, who was concerned about the difficulty of distinguishing between compound medicines of genuine effect and those concocted by empirics and mountebanks: "Although Primrose wrote that it was 'an easie thing for any Physician that knowes the matter of Physick, and the art of compounding medicaments, presently to prescribe such things', what the art consisted of, and whether it had any rules as opposed to ad hoc justifications was doubtful to many opponents of Galenic medicine". 9 The followers of Jean Baptiste van Helmont in particular set themselves up against Galenists who compounded medicines or who

\footnotetext{
${ }^{4}$ Ibid., p. 187.

${ }^{5}$ Frances Willmoth, Sir Jonas Moore: practical mathematics and Restoration science, Woodbridge, Suffolk, Boydell, 1993, p. 73.

${ }^{6}$ Andrew Wear, Knowledge and practice in English medicine, 1550-1680, Cambridge University Press, 2000, pp. 92-5.

${ }^{7}$ Ibid., p. 93.
}

\footnotetext{
${ }^{8}$ Ibid., p. 94, citing William Harrison, The description of England, ed. Georges Edelen, New York, Dover Publications, 1994, p. 266 (text based on Harrison's An historical description of the Island of Britain, London, 1587).

${ }^{9}$ Wear, ibid., p. 95, citing James Primrose, Popular errours or the errours of the people in physick, trans. Robert Wittie, London, printed by W Wilson for Nicholas Bourne, 1651, pp. 24-5.
} 


\section{Alvan Bregman}

mistakenly tried to "correct" simples by traditional means of preparation. Helmontians (such as George Starkey, Marchamont Nedham and George Thomson) espoused chemical preparations which were meant to abstract the virtues of a simple, making the medicine more pure, while in their view compounded preparations would tend only to weaken the simples brought together in Galenic remedies. ${ }^{10}$

Still, it is abundantly clear that physicians frequently prescribed and apothecaries prepared compound medicines. The Pharmacopoeia Londinensis did record the Galenic qualities of simples, and frequently specified the degrees of these qualities. This was not the case for compounds, however. In his translation of the Pharmacopoeia Londinensis, the greater part of which was devoted to compounds, Nicholas Culpeper criticized the original, where "Only and barely the Receipts themselves were quoted by the Colledge.... The Colledg when they made this Dispensatory, never intending their Country so much good as to quote the Vertues". ${ }^{11}$ While Culpeper makes substantial additions to the original to show what diseases the compounds were meant to treat and how they were to be administered, he did not provide information on the qualities of compounds. Moore's chapters can be seen in the context of this vernacularization and popularization of medicine in the Interregnum. He is offering help to practitioners and others who wished to control their mixtures and ensure that the compounds they created were consistent in make-up and effect.

Was alligation alternate something every apothecary already knew? Details about the education of apothecaries are scarce, but the calling was exclusively mastered through an eight-year apprenticeship. During this time, the apprentice "was taught to recognize drugs and to practise the complicated methods then in vogue of compounding and dispensing medicines" These complicated methods of compounding medicines were not taught in textbooks. $^{12}$

The "apothecary" who wrote Tentamen medicinale (1704) came closest to outlining the learning specific to apothecaries, but even so he does not indicate the actual techniques used to compound medicines.

All the common Shop Medicines are made up according to the Prescriptions of the College of Physicians in their Publick Dispensatorys. But there's no further Direction to very few of them, than just to take such Quantities of such Ingredients, and mix them together S.A. and that's all the Directions they have.... I would fain know then if any Person who's ignorant of the Principles and Vertues of Simples, can be capable so to prepare and mix them, that the Composition shall be endued with such determinate and certain Qualities: For the Vertues of many simple Ingredients

\footnotetext{
${ }^{10}$ Wear, ibid., pp. $100-1$.

${ }^{11}$ Nicholas Culpeper (tr.), A physical directory: or, Translation of the dispensatory made by the Colledge of Physitians of London, and by them imposed upon all the apothecaries of England to make up their medicines by whereunto is added, the vertues of the simples, and compounds, 2nd, much enlarged, ed., London, printed by Peter Cole, 1650, p. 56 (Wing C7541).

${ }^{12}$ Chapter on 'The education of the apprentices', in Cecil Wall, H Charles Cameron and E Ashworth Underwood, A history of the Worshipful Society of
}

\begin{abstract}
Apothecaries of London, vol. 1: 1617-1815, London, Published for the Wellcome Historical Medical Museum by the Oxford University Press, 1963, pp. 76-90, on p. 77. See also Juanita Burnby, “"An examined and free apothecary", , in Vivian Nutton and Roy Porter (eds), The history of medical education in Britain, Clio Medica, 30, Amsterdam and Atlanta, Rodopi, 1995, pp. 16-36, p. 18: the apprentice "was taught how to dispense a physician's prescription, how to compound the pharmacopoeial preparations, and how to recognize the drugs, both compound and simple, then in use".
\end{abstract}




\section{Alligation Alternate and the Composition of Medicines}

may be either exalted, alter'd, or quite destroyed, according to the different manner only of mixing them with the other Ingredients of the same Composition. ${ }^{13}$

Physicians of necessity had a university education and Mordechai Feingold has shown that three terms of mathematics were taught by statute at Oxford, at least after 1619, and that mathematics was also a feature of studies at Cambridge. ${ }^{14}$ However, it is not well documented how these studies were specifically applied to medicine. John Securis, in his A detection and querimonie of the daily enormities and abuses co[m]mitted in physick (1566) specified that physicians should be well-tutored in the sciences of "grammer, Logick, musicke, Astronomie, and chiefely (as Plato counsayleth) Arithmetick and geometrie, and also Philosophie". 15 John Henry points out that music was included because of the need to understand the mathematics of ratios which figured in work deriving from Arnald of Villanova in the thirteenth century. Arnald also discussed in detail the problem of compounding medicines according to the qualities of the simples to be combined, drawing upon Arab sources. Arnald believed that drugs were not equally effective in equal doses, but each had its own characteristic dose, which had to be balanced against the other ingredients of a compound and the humoral degree characteristic of the sick patient. ${ }^{16}$

These controversies arose in the Middle Ages, but did not figure in the mathematical writings most read by those who attended the universities in early modern England. Feingold reports that "over half of the inventories of university men who died while in residence ... included at least one or two of the basic arithmetical and geometrical treatises such as those of Gemma Frisius, Recorde, Tunstall, Ramus, Ryff or Euclid."17 However, detailed material about the medical applications of mathematics was not included in texts by these authors, although we shall now proceed to look at Robert Record in some detail, because he did allude to the composition of medicines.

\section{Robert Record's Ground of Artes}

The first substantial English arithmetic, published in 1543, was Robert Record's The grou[n]d of artes: teachyng the worke and practise of arithmetike. ${ }^{18}$ This was arguably to

\footnotetext{
${ }^{13}$ Tentamen medicinale: or, an enquiry into the differences between the dispensarians and apothecarys. Wherein the latter are prov'd capable of a skilful composition of medicines, and a rational practice of physick.... By an apothecary, London, printed, and sold by John Nutt, 1704, pp. 126-7 (ESTCt20981).

${ }^{14}$ Mordechai Feingold, The mathematicians' apprenticeship: science, universities and society in England, 1560-1640, Cambridge University Press, 1984, pp. 24-5.

${ }^{15}$ John Securis, A detection and querimonie of the daily enormities and abuses co[m]mitted in physick concernyng the thre parts therof: that is, the physitions part, the part of the surgeons, and the arte of poticaries, [Londini, In aedibus Thomae Marshi], 1566, A6v-A7r (STC 22143).

${ }^{16}$ John Henry, 'Doctors and healers: popular culture and the medical profession', in Pumfrey,
}

Rossi and Slawinski (eds), op. cit., note 1, above, pp. 191-221, on pp. 208-9. On the medieval theories of Arnald of Villanova and their context, see Michael R McVaugh, 'The two faces of a medical career: Jordanus de Turre of Montpellier', in Edward Grant and John E Murdoch (eds), Mathematics and its applications to science and natural philosophy in the Middle Ages: essays in honour of Marshall Clagett, Cambridge University Press, 1987, pp. 301-24 (especially pp. 303-6). John Dee cited Arnald (and other predecessors) in his Mathematicall praface to Euclid (1570), see note 30 below.

${ }^{17}$ Feingold, op. cit., note 14 above, p. 116

${ }^{18}$ Robert Record, The grou[n]d of artes: teachyng the worke and practise of arithmetike, moch necessary for all states of men. After a more easyer [et] exacter sorte, then any lyke hath hytherto ben set forth: with dyuers newe additions, London, R Wolfe, 1543 (STC 20797.5). 


\section{Alvan Bregman}

become "the most popular arithmetical work in England" for more than a century; editions continued to appear right up to $1699 .{ }^{19}$ Record was both a serious mathematician and a brilliant teacher. As he announces in his preface, the intended audience was not "the learned sort", but "the symple ignorant, (whiche nedeth most helpe)". ${ }^{20}$ His text was written as a dialogue between an experienced master and an eager student; examples were carefully and patiently worked out; the expositions were numerous, detailed and clear. Record wrote in the vernacular for an English audience so as to promote all aspects of improvement in the commonwealth. Thus, as Record expressed at length when he later re-dedicated his work to King Edward VI, his enterprise was meant to be of the utmost practicality.

In 1552, Record amplified his arithmetical text with, among other material, a "second part touchyng fractions". This new section included additional chapters on various rules of proportion, including "The Rule of Alligation", so-called "for that by it there are divers parcels of sundry pieces, and sundry quantities alligate, bounde, or myxed togyther". ${ }^{21}$

The rule of alligation, we are told, "hath great use in composition of medicines, and also in myxtures of mettalles, and some use it hath in myxtures of wynes, but I wyshe it were lesse used therein than it is now a daies". Despite Record's regret about the adulteration of wine, the first problem the Master uses to exemplify his discussion of alligation in fact deals with mixing wines; the second involves a merchant mixing spices; and the remainder involve the mixing of metals. None of the examples involve medicine, although the merchant's spices are once called "drugges". ${ }^{22}$

One of Record's main points is the variety of solutions that could be derived from any set of data manipulated by alligation. The Master warns the Scholar that many of these solutions would be useless for practical purposes: "Meruaile not therat, for some questions of this rule may be varied aboue 1000 waies: but I would haue you forget suche fantasies, tyll a tyme of more leysure". After working through six variations on a single problem, the Master ends the section: "And this shall suffise nowe for the rule of alligation or mixture, for by these exaumples may you easily coniecture suche other as do appertayn to it, as wel for the due workyng as for varietie of drawyng the lines of combination". ${ }^{23}$

The application of alligation to the composition of medicines was not then a substantive feature of Record's arithmetic. Since Record was a physician, and described as such on the title-pages of many editions of his works, it is not surprising that he did briefly consider the importance of numbers to "Physike" in his writings. For example, in his 'Preface to the gentle Reader' in The whetstone of witte $(1557),{ }^{24}$ which carries on where The grounde of

\footnotetext{
${ }^{19}$ Francis R Johnson and Sanford V Larkey, 'Robert Recorde's mathematical teaching and the Anti-Aristotelian movement', Huntington Library Bulletin, 1935, 7: 59-87, p. 62.

${ }^{20}$ Robert Record, The ground of artes teachyng the worke and practise of arithmetike, Imprinted at London, by Reynold Wolff, 1552, p. 7 (A4r) (STC 20799.3). The first edition was dedicated to "Rychard Whalleye Esquyer"; later, when a new dedication was addressed to the young King Edward,
}

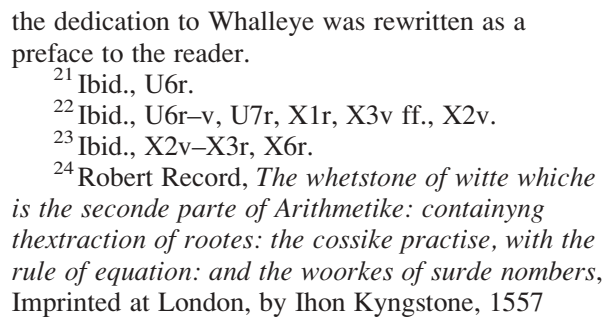
Imprinted at London, by Ihon Kyngstone, 1557 (STC 20820). 


\section{Alligation Alternate and the Composition of Medicines}

artes leaves off, to teach more complex arithmetical operations, such as the extraction of roots, and algebra, or "the arte of cossike nombers", Record says:

And as for Physike, without knowledge and aide of nomber is nothynge. Wee see that nature in generation, bothe of manne and beastes, yea and of al thynges els doeth obserue nomber exactly. As well in the tyme of formation, as in the monethes of quickenyng, and of birthe. The misteries of the seuenth and nineth monethes are sufficiente testimonies therein. Beside that from the fourthe monethe til the seuenth many thynges bee permitted, that els bee not conueniente. For the use of the pulse, and for criticalle dayes, beside the proportion in degrees in simple medicines, and mixture of compounde medicines, and other infinite maters, what nomber can doe and what aide it giueth, onely the ignoraunte doe doubte. ${ }^{25}$ [Emphasis added.]

In 1561, three years after Record's untimely death, a new edition of The grounde of artes appeared "of late ouerseen \& augmented with new \& necessarie additions" by John Dee. In actual fact, although "Dee's substantive additions to Recorde's text were ... rather slight," 26 two new paragraphs were added at the end of the section on alligation, as follows:

Sc[olar], Syr, Albeit it pleased you, while err, to put me from my musing at the manyfold varieties, $\mathrm{y}^{\mathrm{t}}$ may fall in these combinations, and termed them fantasies, yet my fantasie giueth me $\mathrm{y}^{\mathrm{t}}$ the consideration of this should in many other exaumples and cases of importaunce be very needefull, and the knowledge of it most profitable. Therefore ye may well think that at an other tyme conuenie[n]t I will request you to ayde me herein.

$\mathrm{Ma}[\mathrm{ster}]$. Truth it is, that this consideration may fall in practise as well politike, as philosophical, and sundry waies in them be applied, therefore whan time shall fall feete for the discussing of this consideration, you shal not want my helping hand. ${ }^{27}$

Although these paragraphs seem to promise future additions to the discussion, neither Dee nor those responsible for the many later editions of The ground of artes ever did expand in detail on the section concerning alligation. Expansions in other areas did occur. For example, in 1582, John Mellis added a third section on 'Rules of Practize ... with diverse such necessary Rules, as are incident to the trade of Merchandise'. ${ }^{28}$ However, Mellis and other editors did not consider either alligation or medical applications further in revising Record's arithmetic. We must look elsewhere for these developments. ${ }^{29}$

\footnotetext{
${ }^{25}$ Ibid., A1; sig. b2.

${ }^{26}$ Nicholas H Clulee, John Dee's natural philosophy: between science and religion, London and New York, Routledge, 1988, pp. 85-6. Joy Easton enumerated most of the minor changes made by Dee, but does not mention the quoted paragraphs: Joy B Easton, 'The early editions of Robert Recorde's Ground of artes', ISIS, 1967, 58: 515-32, and particularly pp. 529-32.

${ }^{27}$ Robert Record, The grounde of artes: teaching the worke and practise of arithmetike, both in whole numbres and fractions, after a more easyer and exacter sorte then any like hath hitherto been sette forth: made by $M$. Robert Recorde doctor of physik, and now of late ouerseen \& augmented with new \& necessarie additions, Imprinted at London, by Reginalde VVolfe, 1561, Z1v (STC 20800).
}

\footnotetext{
${ }^{28}$ Robert Record, The grounde of artes teaching the perfecte vvorke and practise of arithmetike,... augmented by M. Iohn Dee. And now lately diligently corrected, [and] beautified with some new rules and necessarie additions: and further endowed with a thirde part, of rules of practize, abridged into a briefer methode than hitherto hath bene published: with diverse such necessary rules, as are incident to the trade of merchandize. Whereunto are also added diuers tables [and] instructions ... By Iohn Mellis of Southwark, scholemaster, [London], imprinted by I Harrison, and H Bynneman, 1582 (STC 20802).

${ }^{29}$ Dee added a poem at the very end of the 1582 volume, "To the earnest Arithmetician" (2Y6v), which advised the student to study Euclid. Although Dee may seem simply to be advertising his recent edition of Euclid, in doing so he was also being true to Record,
} 


\section{Alvan Bregman}

\section{John Dee's Mathematical Praface to Euclid}

While Record did not live to elaborate on "the proportion in degrees in simple medicines, and mixture of compounde medicines", his first editor went on to consider the application of mathematics to medicine in Iohn Dee his Mathematical praface, which appeared as the important introduction of the first English translation, by Henry Billingsley, of Euclid's The elements of geometrie in $1570 .{ }^{30}$ Most commentators have been struck by the broad theoretical, philosophical and even mystical interests Dee displayed in this work. However, we will concentrate on the more basic and practical aspects of mathematics that Dee described.

In his synoptic preface, Dee systematically outlined the numerous fields which ultimately depended upon mathematics. The Praface culminated in a large tree diagram or "Groundplat" of the "Sciences, and Artes Mathematicall". ${ }^{31}$ It is strange that medicine was not defined as a separate mathematical art or science in the "Groundplat", since medicine was the subject of the longest and most detailed example of the use of mathematics given in the Praface proper. Leading up to this subject, Dee began by pointing to the use of arithmetical rules, by "all kynde of Marchants". ${ }^{32}$ For example, the "Rule of Alligation, in how sundry cases, doth it conclude for them, such precise verities, as neither by naturall witt, nor other experience, they, were hable, els, to know?" But not only merchants, mintmasters and goldsmiths derived benefit from mathematics:

And the honorable Physicia[n]s, will gladly confesse them selues, much beholding to the Science of Arithmetike, and that sundry wayes: But chiefly in their Art of Graduation, and compounde Medicines. And though Galenus, Auerrois, Arnoldus, Lullus, and other haue published their positions, aswell in the quantities of the Degrees aboue Temperament, as in the Rules, concluding the new Forme resulting: yet a more precise, commodious, and easy Method, is extant: by a Countreyman of ours (aboue 200. yeares ago) inuented. [In margin: "R.B.,"33] And forasmuch as

who had said that arithmetic was a prerequisite for the more advanced study of geometry (and after that, astronomy), and who had written his own texts to teach those advanced arts.

${ }^{30}$ Euclid, The elements of geometrie of the most auncient philosopher Euclide of Megara. Faithfully (now first) translated into the Englishe toung, by $H$. Billingsley ... With a very fruitfull praface made by M.I. Dee, specifying the chiefe mathematicall scie[n]ces, what they are, and wherunto commodious: where, also, are disclosed certaine new secrets mathematicall and mechanicall, vntill these our daies, greatly missed, Imprinted at London, by Iohn Daye, 1570 (STC 10560). Most widely available in a facsimile edition: John Dee, The mathematicall praface to the elements of geometrie of Euclid of Megara (1570), with an introduction by Allen G Debus, New York, Science History Publications, 1975.

${ }^{31}$ There are two main branches, "Principall" and "Derivative": of the Principall kinds are

"Arithmetike" and "Geometrie", and these are each subdivided into "Simple" and "Mixt" species.

Derivative mathematical applications may be related to the Principalls under the terms of "Arithmetike vulgar" (such as "Arithmetike of Proportions" or "Arithmetike Circular") and "Geometrie vulgar", either relating to things at hand (as by "Mecometrie", "Embadometrie" and "Stereometrie") or at a distance (such as "Geodesie", "Geographie", or

"Stratarithmetrie"); or they may have their own names, such as "Perspective", "Astrologie", "Navigation" and sixteen others, some quite arcane, such as "Archemastrie,- - Which teacheth to bring to actuall experience sensible, all worthy conclusions, by all the Artes Mathematicall purposed: and by true Naturall philosophie, concluded".

${ }^{32}$ Dee, Praface, in Euclid, op. cit., note 30 above, $* 2 \mathrm{v}$.

33 "R.B." is likely to refer to the controversial Roger Bacon, and possibly the manuscript was in Dee's possession. In Bacon's Radix mundi there is a chapter called 'Of the differences of the medicine, and proportions used in projection'. See the translation prepared by William Salmon in his Medicina practica, or, Practical physick shewing the method of curing the most usual diseases happening to humane bodies...: to which is added, the philosophick works of Hermes Trismegistus, Kalid Persicus, Geber Arabs, Artesius 


\section{Alligation Alternate and the Composition of Medicines}

I am vncertaine, who hath the same: or when that litle Latin treatise (as the Author writ it,) shall come to be Printed: (Both to declare the desire I haue to pleasure my Countrey, wherin I may: and also, for very good profe of Numbers vse, in this most subtile, and fruteful, Philosophicall Conclusion,) I intend in the meane while, most briefly, and with my farder helpe, to communicate the pith therof vnto you. ${ }^{34}$

Dee goes on to show that when medicines of different qualities (i.e., the Galenic categories, hot, cold, moist and dry) are mixed, it is possible to calculate the quality of the resulting mixture when their quantities are the same. This is an extremely basic arithmetical function, involving no more than calculating a mean. However, the calculation of mixtures when the quantities are different is more complicated. In this case, it is necessary to calculate using rules of proportion, which Dee frames in terms of "the Arte of Algiebar" (i.e., algebra). His lengthy example supposes the mixture of just two medicinal simples of unequal quantity and quality. Dee suggests that the way to measure more than two such medicines is to reiterate the process, that is, calculate for two simples, take the result and calculate with the third simple, and so on.

Dee seems very proud of this demonstration, although it would now appear to be so extremely basic. It is clear that he believes himself to be promulgating a new solution to an important problem which before had been approached only through the action of estimation. "For, here, you may perceiue that the litle finger of Arithmetike, is of more might and contriuing, then a hundred thousand mens wittes, of the middle sorte, are hable to perfourme, or truely to conclude, with out helpe thereof". 35

\section{Alligation from Dee to Moore}

Despite its intrinsic importance to English science, the Dee/Billingsley translation of Euclid was not reprinted until 1651, nor were Dee's medical applications of mathematics recast or improved upon until used by Moore in his Arithmetick at around the same time. In the intervening decades between Dee and Moore, many arithmetic books appeared and discussed alligation, but none considered its medical applications. In these arithmetics, the presentation of the rules of alligation came to be fixed towards the end of arithmetical texts, in one or more sections following the "Golden Rule" or "Rule of Three", used to manage proportions. ${ }^{36}$ We shall look at three examples, by Humfrey Baker, Thomas Hylles and Edmund Wingate, to show the variety of treatment accorded to alligation over this period.

In some arithmetics, the process of alligation was explained with one or two examples and not commented upon at length. For example, in The well spryng of sciences whiche

\footnotetext{
Longaevus, Nicholas Flammel, Roger Bachon and George Ripley. ... together with a singular comment upon the first book of Hermes, the most ancient of philosophers, London, printed for T Howkins, J Taylor, and J Harris, 1692 (Wing S434). (See Table of Contents and pp. 585-642.) Salmon, who will be discussed later in this article, says he translated the Radix mundi from a "manuscript out of the library of a learned man, and our particular friend, a Doctor of Physick, who set a great value upon it, and not undeservedly" (Preface B3v).
}

\footnotetext{
${ }^{34}$ Dee, Praface, in Euclid, op. cit., note 30 above, $* 3$ r.

${ }^{36}$ Chapters on alligation were normally followed only by chapters on the "Rule of Falsehood" or of "False Positions", which was carried out by supplying any reasonable figure to a problem, solving the problem using this figure, and then using the result as the basis for calculation using the "Golden Rule".
} 


\section{Alvan Bregman}

teacheth the perfecte woorke and practise of arithmeticke, ${ }^{37}$ Humfrey Baker gives two examples, one featuring a goldsmith, the other a taverner. Baker's explanation is not straightforward, and he does not say what to do with more complex operations, for example, those involving an odd (rather than an even) number of ingredients.

In other cases, extended explanations of alligation do appear. Thomas Hylles has a particularly full presentation in his book, The arte of vulgar arthmeticke (1600). ${ }^{38}$ This work is divided into three books, the first entitled Nomodidactus numerorum, the second Portus proportionum, and the third Musa mercatorum - the chapter on alligation is part of the second book, on proportion. Hylles's arithmetic is both scholarly-it refers frequently to earlier theoretical and practical writers, especially Petrus Ramus-and is aimed at a popular audience: the main precepts are given in the form of rhyming verses to make them easier to remember and the discussion is given in the form of a dialogue between a teacher (Philomathes) and a student (Eumathes), after the manner of Record and Ramus.

Hylles is thorough. He notes at the outset of his discussion of alligation that all measures or quantities need to be the same before proceeding. He separates the procedure into its two main parts, alligation medial and alligation alternate. He supplies names and definitions for all aspects of the problem. For example, quantities greater than the mean are called "greater extremes", quantities less than the mean are called "lesser extremes". Alligation alternate, which presupposes that one has a known result to achieve through the mixture of simples, is treated first. The student is told to order all the quantities from the greatest to the least before linking together a greater with a lesser extreme. Through a number of wellexplained examples involving the mixture of grains, wines, gold and silver the student is introduced to numerous complexities, such as what to do when there is only a single lesser or greater extreme against which several of its opposites need to be linked, or alligated.

Finally, Hylles explains the less complex alligation medial, which "seeks out the meane, By aid of proportion doubly compounded". The operation is demonstrated with a problem involving the mixture of grains of different quantities and value. It is easy to determine the mean value of a measure of the mixture simply by using the golden rule of proportions. When the student asks for more problems to solve, Hylles offers one with a medical association, involving "An Appothecarie making a certayne dredge poulder" containing so many pounds each of "Sugarcandie", "Liquirice", "Annis" and "fennel"; the question being, at what price ought one to sell the resulting mixture? ${ }^{39}$ That being easily solved, the student then goes on to other problems involving the mixtures of cloves, a merchant's pricing of "Holland cloth", and several involving calculations done by a goldsmith. While Hylles shows how alligation medial might be relevant to an apothecary's practice, the problem presented involves pricing alone and is not concerned with the medicinal qualities of the ingredients. Hylles does not specifically draw attention to the use of alligation alternate for this purpose.

\footnotetext{
${ }^{37}$ Humphrey Baker, The well spryng of sciences whiche teacheth the perfecte woorke and practise of arithmeticke, Imprinted at London, by Ihon

Kyngston for Iames Rowbothum; 1568, leaves 148r-152r (STC 1210).

${ }^{38}$ Thomas Hylles, The arte of vulgar arithmeticke both in integers and fractions, ... Newly collected,
}

digested, and in some part deuised by a welwiller to the mathematicals, Imprinted at London, by Gabriel Simson, 1600 (STC 14040.7). The chapters on alligation are on ff. 192r-208r (2L4r-2N4r).

${ }^{39}$ Ibid., leaf 204r (2M8r). 


\section{Alligation Alternate and the Composition of Medicines}

Arguably the most important arithmetic in English in the first half of the seventeenth century was Edmund Wingate's Arithmetique made easie, in tvvo bookes (1630). ${ }^{40}$ The first of these books was sub-titled: of Naturall arithmetique ... according to the ancient vulgar way, without dependance vpon any other author for the grounds thereof. The second was called: of Artificiall arithmetique, discovering how to resolve all questions of arithmetique by addition and subtraction. This second book contained the first popularization in English of John Napier's and Henry Briggs's revolutionary work on logarithms. In his preface, Wingate betrays his great excitement about logarithms, bound to facilitate the solution of most complex arithmetical operations. He also enthusiastically introduces a new calculating "Instrument" of his own invention, based on logarithms, for this purpose.

Like Hylles before him, Wingate divides up "The Rule of Alligation" into the simpler "Alligation Mediall" to discover a mean, and the more complex "Alligation Alternate". In a clearly organized way, Wingate provides a comprehensive outline of numerical manipulations related to the latter technique. For example, he delineates two varieties of alligation alternate, called "Alligation Partiall" and "Alligation Totall". ${ }^{41}$ In explaining these procedures, Wingate naturally gives many examples, all of the traditional kind, dealing with the mixture of different kinds of grains and metals. In chapter 21 of his second book, on Artificiall arithmetique, Wingate returns to the rule of alligation, but no additional explanation is provided about the technique itself since the point of the chapter is to substitute logarithms for natural numerical terms in performing the operation. The examples are once again traditional, involving mixtures of grain, wine, gold and metals. Medicinal operations are not ruled out, but they are not included in the discussion. Despite its importance as an arithmetic and its expansion of information about the process of alligation, Wingate, like so many of his predecessors, did not provide detailed discussion about the medical applications of mathematics.

\section{Alligation Alternate and the Composition of Medicines (1650-1656): Jonas Moore's Arithmetick (1650)}

This then, is the background against which we may view Jonas Moore's claims of originality in his propositions concerning medicine, which he published in his Arithmetick of $1650 .{ }^{42}$ Frances Willmoth suggests, in her authoritative and detailed biography of

\footnotetext{
${ }^{40}$ Edmund Wingate, Arithmetique made easie, in tvvo bookes. The former, of naturall arithmetique: containing a perfect method for the true knowledge and practice of arithmetique, according to the ancient vulgar way, without dependance vpon any other author for the grounds thereof. The other of artificiall arithmetique, discovering how to resolve all questions of arithmetique by addition and subtraction. Together with an appendix, resolving likewise by addition and subtraction all questions, that concerne equation of time, interest of money, and valuation of purchases, leases, annuities, and the like, London, printed [by Miles Flesher] for Phil. Stephens and Chr. Meredith, 1630 (STC 25849).

${ }^{41}$ It appears that "Alligation Partiall" is nothing more than doing a reduced proportional calculation
}

based on the differences enumerated during an alligation alternate procedure; while "Alligation Totall" involves an increased proportional calculation.

${ }^{42}$ Jonas Moore, Moores arithmetick: discovering the secrets of that art in numbers and species. In two bookes: the first, teaching (by precept and example) the ordinary operations in numbers, whole and broken ... the second, the great rule of algebra in species, resolving all arithmeticall questions by supposition: with a canon of the powers of numbers, London, printed by Thomas Harper for Nathaniel Brookes, 1650 (Wing M2563). While the imprint date is 1650, Moore's 'Epistle to the Reader' is dated 30 October 1649, and in it he says that "it is now two years since this peece was delivered to be printed" (A5v). 


\section{Alvan Bregman}

Moore, that the propositions "may simply reflect his association with Dr [John] Bathurst's son, [Christopher Bathurst] the dedicatee of Moore's second book; in any case they offered him, or his publisher, one more means of emphasising the work's practicality". "It is undoubtedly true that the intended practicality of Moore's Arithmetick was one of its chief selling points, but we can now see that the chapter on medicines was indeed an innovation in the genre.

It is also worthwhile to reconsider Moore's dedications. The dedicatees of the first book (containing the chapters on alligation and on medicines), were Moore's personal sponsors, Sir William Persall (later a member of the Royal Society), Edmund Wild (a wealthy member of Parliament) and Nicholas Shuttleworth (a benefactor of Moore), none of whom seem to have been physicians. ${ }^{44}$ The dedication to the Bathursts precedes Moore's second book, on artificial arithmetic (i.e., on logarithms) which does not include the chapter on the composition of medicines. ${ }^{45}$ Dr John Bathurst was no ordinary doctor, for despite his courtly leanings, he was named one of Oliver Cromwell's personal physicians and went on to represent Richmond, Yorkshire, in the Protector's second Parliament. ${ }^{46}$ Moore, as a former tutor of the exiled Duke of York, may once again be seen in this dedication to be distancing himself from his Royalist associations. It is notable that dedications to all these sponsors were dropped in the second edition of 1660, following the Restoration, and replaced by a dedication to the Duke of York, as Lord High Admiral.

At the outset of his chapter 'Of Alligation', Moore outlines the main uses of the procedure, setting apart for the first time the medical use of alligation from ordinary commercial applications: "This Rule is very necessary to mix quantities of severall Rates, and to discover the mean price, as also in compositions of medicines, for both the quantity and price". ${ }^{47}$ While the initial chapter explains the varieties of alligation through examples dealing with mixtures of grains, wines, precious metals, cloth, and the ingredients for bread, the chapter which follows elucidates eight "divers usefull Propositions concerning the composition of Medicines". ${ }^{48}$ Propositions 1, 2, 3 and 8 pertain to medicines as ordinary mixtures and commodities, but the others (Propositions 4 to 7 ) talk about the "temperament" and "quality" of medicines, that is, about ways of controlling the efficacy of medicine from a Galenic perspective.

Prop. 1: To augment a Medicine in quantity, keeping the proportion given.

Prop. 2: To diminish a Medicine in quantity, keeping still the Proportion of the given quantities.

Prop. 3: To finde out what Quantity of any Ingredient or simple is contained in any Quantity of a Composition.

Prop. 4: To know the exact temperament and quality of any Medicine whatsoever.

Prop. 5. To augment in Quality a Medicine to any degree proposed.

\footnotetext{
${ }^{43}$ Willmoth, op. cit., note 5, above, p.73.

${ }^{44}$ See ibid., pp. 42,18 .

${ }^{45}$ The second part, or book, of Moore's Arithmetick was devoted to Algebra in species, that is, to more difficult and theoretical mathematical laws and applications. The dedication on Aa2 reads, "To his much honoured Friend, Iohn Bathurst, Doctor of Physicke, One of the Fellowes of the Colledge of Physitians of London, a judicious Favourite of best meriting studies. For the encouragement of his eldest
}

son, Christopher Bathurst, An early and hopefull proficient in the Arts Mathematicall, and all other Literature. The Author maketh this Second Book publique, and Dedicateth the Same" (Aa2).

${ }^{46}$ Elizabeth Land Furdell, The royal doctors, 1485-1714: medical personnel at the Tudor and Stuart courts, Rochester, NY, University of Rochester Press, 2001, p. 146

${ }_{47}^{47}$ Moore, op. cit., note 42 above, p. 151.

${ }^{48}$ Ibid., p. 169. 


\section{Alligation Alternate and the Composition of Medicines}

Prop. 7 [i.e., 6]. To diminish a Medicine in quality from any degree whatsoever.

Prop. 7. To reduce any Medicine proposed to any degree of quality whatsoever.

Prop. 8. To finde out the value or price of any quantity of a Medicine, having the values of the simples first given. ${ }^{49}$

Moore even gives some explanation about the medical theory involved: "The qualities, faculties, and vertues of Medecines are considered in respect of us and not of themselves", ${ }^{50}$ for these values are determined by the changes brought about on the person who takes the medicine. Thus, "those simples are called temperate, that brings no change in our bodies in respect of heate, cold, moistures, and drynesse; those hot which have power of heate", and so on. The potential number of combinations of quality is very large. In this work, Moore goes considerably beyond what John Dee had shown in his Mathematical praface. Dee used relatively complex terms to show how to determine a single quality of a mixture of only two simples. Moore extends this, for the arithmetical procedure of alligation alternate explicitly allows the compounder to control and analyse effectively the complex make-up of his medicines. The connection with medical literature is made plain when Moore quotes from Daniel Sennert's Institutionum medicinae libri V:

It is requisite for an Apothecary to know the resultment of any Medicine, as Zenertus affirms Lib. 5. Instit. Pars 3. Chap. 1 which is taught the last; and in the same Chapter, amongst many other observations, he saith, Interdum vis Medicamenti est debilis, quam validioris admistione intendere; contra nonnunquam vehementior, quam debilioris additione remittere oportet. ${ }^{51}$

Sennert first published his book in Wittenberg in 1611; it reached its fourth edition, much enlarged, in 1644. Moore makes reference to Sennert's chapter on the composition of medicines. Sennert's work was first published in English as The institutions or fundamentals of the whole art, both of physick and chirurgery, in $1656^{52}$ and was then reissued as part of Nine books of physick and chirurgery written by ... Dr Sennertus. The first five being his Institutions of the whole body of physick: the other four of fevers and agues: with their differences, signs, and cures. ${ }^{53}$ Moore was thus making use of a source not yet available in English.

While Sennert argued for the importance of correctly composing medicines and their doses, he did not show how that was to be done. Sennert defined a panoply of apothecaries' measures, from the less precise "heape", "little handfull", and "great handfull" to the more precise, "chalcus" (= two grains), "dicalcon" or "siliqua" (= four grains), and so on. ${ }^{54}$ Besides explaining exactly how to compute the mixture of compounds, Moore simplified the task considerably by outlining only five invariable weights used by apothecaries, namely, pounds, ounces, drams, scruples and grains. ${ }^{55}$

\footnotetext{
${ }^{49}$ Ibid., pp. 171, 173, 174, 178, 181, 182, 186.

${ }^{50}$ Ibid., p. 170.

${ }^{51}$ Ibid., p. 178. For translation of the Latin, see note 53 below.

${ }^{52}$ Daniel Sennert, The institutions or fundamentals of the whole art, both of physick and chirurgery, divided in to five books, London, printed for Lodowick Lloyd, 1656 (Wing S2535).

${ }^{53}$ Daniel Sennert, Nine Books of physick and chirurgery, London, printed by J M for Lodowick
}

Lloyd, 1658 (Wing S2537). The Latin passage cited by Moore is here translated: "for if the vertue of the medicine be weake, tis to be strengthned $[\mathrm{sic}]$ by mixture with more vehement, if any faculty be deficient, tis to be mixt" (p. 410).

${ }^{54}$ Ibid., pp. 412-13.

${ }^{55}$ Moore, op. cit., note 42 above, p. 169. Other medical writers besides Sennert exhibited similar designs. For example, Philip Barrough, The method of physick containing the causes, signes, and cures 


\section{Alvan Bregman}

As mentioned above, Moore's Arithmetick was reissued in 1660, with a new dedication, appropriate to the Restoration, to James, Duke of York, in his capacity as Lord High Admiral, and to Sir Edward Montague, the Vice-Admiral. While there were also numerous revisions and additions made to the text itself, carried out by a "Mr. John Leake, (an able Mathematician, and good Friend of mine)", ${ }^{56}$ the chapters on alligation alternate and the composition of medicines were not changed. It is notable, however, that mention of the medical propositions were removed from the title-page, since they were no longer unique, as we shall see. By the time the third edition appeared in 1688, Moore had become well known as the surveyor who oversaw the draining of the East Anglian fens, and he was an active member of the Royal Society. Again, no changes were made to the chapters on alligation, and Moore apparently never returned to considering the medical applications of mathematics.

\section{Edmund Wingate's Arithmetique made Easie, Enlarged by John Kersey}

In 1650, the same year that Moore's Arithmetick appeared, Edmund Wingate published a second edition of his Arithmetique made easie, ${ }^{57}$ for which he commissioned John Kersey to go over the first part of the text, on "Natural Arithmetique", and improve it with "divers insertions in severall places". Kersey was also given leave to add "certain Chapters (intirely his own) $" 58$ in an Appendix which was meant to stand alone for practical purposes and function as an introduction to Wingate's second book on Arithmetique artificiall, especially devoted to logarithms.

Among Kersey's original contributions was a geometrical proof for the rule of alligation. Moore had intended to provide such a proof, presumably to be included in 'Locus resolut', one of five further works Moore promised to his readers in 1650. 'Locus resulot' was to contain "Euclid's Data, with sundry propositions analitically invented, and Geometrically solved and demonstrated", 59 but if written, it was never published. When the second edition of Moore's Arithmetick appeared in 1660, two new treatises were appended-one being on the ellipsis, the other being William Oughtred's study on conical sections-but no geometrical demonstrations appeared and, as we have seen, the chapters on alligation and on the composition of medicine were not revised. Possibly one reason the 'Locus resolut' was no longer required was because Kersey had supplied various geometrical demonstrations in the appendix to Wingate's Arithmetique made easie that we are discussing. ${ }^{60}$

of inward diseases in mans body,... whereunto is added, the form and rule of making remedies and medicines, which our physicians commonly use at this day; with the proportion, quantity, and names of each medicine, London, printed by Abraham Miller, and are to be sold by John Blague and Samuel Howes, 1652 (Wing B921). Barrough enumerates the ingredients for a wide variety of medicines, but does not explain how calculations were to be done in producing compounds. It was left to the medical astrologer-practitioner, William Salmon, to outline the details of the procedures (see below).

${ }^{56}$ Jonas Moore, Moor's arithmetick, London, Printed by J G for Nath. Brook, 1660, A6r (Wing M2564).

\footnotetext{
${ }^{57}$ Edmund Wingate, Arithmetique made easie, or, A perfect methode for the true knowledge and practice of natural arithmetique according to the ancient vulgar way without dependence upon any other author for the grounds thereof, London, printed by J Flesher for Phil Stephens, 1650 (Wing S2997).

${ }^{58}$ Ibid., Preface, sig. A3v.

${ }^{59}$ Moore, 'The Epistle to the Reader', op. cit., note 42 above, A6.

${ }^{60}$ Kersey also supplied geometrical proofs for other operations, for example, "a Geometricall demonstration of the Rule of False, by two Positions" (Wingate, op. cit., note 57 above, p. 337).
} 


\section{Alligation Alternate and the Composition of Medicines}

The fourth of Kersey's appended chapters was headed 'Containing a Geometricall Demonstration of the Rule of Alligation alternate, and the use of the said Rule in the composition of Medicines'. Kersey's geometrical proof for alligation alternate was new to English arithmetics but was based on a briefer proof by the French mathematician, Pierre Herigone. In his section 'Of the Composition of Medicines', Kersey carefully cited his predecessors in a marginal note: "See Mr. J. Dee his Mathem. Preface also P. Herigone Tom 2. and Mr. Mores, Arithmetique".61

Pierre Herigone was the author of the bilingual Cursus mathematicus, nova, brevi, et clara methodo demonstratus $=$ Cours mathematique, demonstre d' une nouvelle, briefve, et claire methode (1634). In it, Herigone attempted to create a new and (supposedly) simplified system of mathematical notation, but this did not prevail, and his beautifully printed volumes never became standard. Indeed, remaining copies of the first five volumes were reissued with new title-pages in 1644 when a sixth, supplemental, volume was published. ${ }^{62}$

In the second volume of the Cours mathematique, ${ }^{63}$ Herigone included a brief exposition "de la reigle d'alligation", with three examples, two involving a "maistre monnoyeur" and the third an "apotiquaire" who has four kinds of medicines, of which the first is hot in the fourth degree, the second is hot in the second degree, the third is cold in the first degree and the fourth is cold in the third degree. The question was, how much of each medicine must one take so that the resulting compound is of the first degree of heat? After showing how this problem can be solved by the rule of alligation alternate, Herigone introduced his geometrical proof. This proof is somewhat circuitous and introduces certain references to Euclidean propositions that are not strictly necessary but do indicate the importance of proportion in the practical mathematics of the era.

Kersey used the same geometrical construction as Herigone, but expanded the explanation considerably. Kersey's proof showed "that if the summe of the Products, arising from the Multiplication of the prices (or qualities) of two things miscible, by the respective Alternate differences between the mean price and said two prices miscible, be divided by the summe of the said differences, the Quotient will be the mean price". ${ }^{64}$ The careful reader, familiar with Herigone's "simplified" but non-standard notation and able to follow Kersey step by step, may still feel that the proof is opaque. It is noteworthy that after Wingate's death in 1656, Kersey provided an entirely different proof for alligation alternate in future editions of Arithmetique made easie (henceforth published as Mr. Wingate's arithmetick), though his discussion of 'The Composition of Medicines' remained the same. Kersey's new proof began with a simpler construction which was merely a vestige of the earlier geometrical proof, and then abandoned Herigone and geometry in favour of an entirely different sort of proof, this one algebraic. Regardless of which proofs were studied, the same conclusion could be derived: alligation alternate could be counted on to work, and by implication, so too would the propositions concerning medicines. Geometrical and

\footnotetext{
${ }^{61}$ Ibid., pp. 319, 323.

${ }^{62}$ This according to a note in the British Library's copy, which also indicates that the sixth volume included "the first impression of Fermat's maxima and minima, tangents, etc."

${ }^{63}$ Pierre Herigone, Tome second du Cours mathematique, contenant l'arithmetique practique: le
}

calcul ecclesiastique: \& l'algebre, tant vulgaire que specieuse, avec la methode de composer \& faire les demonstrations par le retour ou repetition des vestiges de l'Analyse, A Paris, chez Simeon Piget, 1644, pp. 99-102.

${ }^{64}$ Kersey in Wingate, op. cit., note 57 above, p. 323. 


\section{Alvan Bregman}

algebraic proofs aside, however, Kersey's section was mainly a reworking of Moore, attesting both to the priority and importance of the material in the earlier textbook, though Kersey reduced Moore's eight original propositions to three:

Prop. 1. Having divers Simples whose qualities are known, to make a composition or mixture of them, in such manner that the quality of the Medicine may be some mean amongst the qualities of the Simples, and the quantity thereof any quantity assigned.

Prop. 2. A medicine being compounded of divers Simples whose qualities and quantities are known, to finde the degree of the Form resulting, viz. the exact Temperament of the medicine.

Prop. 3. To augment or diminish a medicine in qualitie according to any degree assigned. ${ }^{65}$

Kersey covered the same ground with respect to the temperament and qualities of medicine as Moore did in his propositions 4 to 7 , but treated the diminishing and increasing of temperaments as aspects of the same topic, where Moore treated them in separate propositions. Kersey referred only briefly to Moore's propositions 1, 2, 3, and 8 when he ended his discussion by stating that "The augmenting or dimishing of a medicine in respect of quantity; Also the finding of the value of any quantitie of a medicine, the prices of the Ingredients being known, will bee familiar to such as understand the Rule of Proportion, and therefore I shall not insist upon them". ${ }^{66}$

Kersey, who died around 1690, did not again tinker with his proof, except as mentioned, or with his discussion of alligation alternate and the composition of medicines. His enlargement of $M r$. Wingate's arithmetic went into its tenth edition in 1699 . The enduring popularity of the Wingate/Kersey arithmetic meant that a chapter on the composition of medicines appeared in subsequent editions, edited by others, well into the eighteenth century. ${ }^{67}$

\section{Thomas Willsford's Arithmetick, Naturall, and Artificiall: or, Decimalls (1656)}

The third arithmetic of the 1650 s to feature chapters on alligation alternate and the composition of medicine was by Thomas Willsford, whose Arithmetick, naturall, and artificiall appeared in $1656 .{ }^{68}$ Willsford did not supply proofs, but presented his chapters, called "paragraphs", without theoretical preface, as if their subjects were an expected feature of the arithmetic genre. Paragraph XIII, which is in a long concluding section on "Arithmeticall illustrations in the rules of proportion", "[s] heweth the solving of divers necessary questions by the Rules of Alligation, in the composition of Physicall simples, according to their qualities, as Hot, Cold, Drie, Moyst, with the quantities of those Simples augmented, or diminished according to any degree prescribed". ${ }^{69}$ Willsford had a remarkably clear and well-organized method of presentation. He began by considering the mixture of only two simples and then added another simple into the calculation in each subsequent

\footnotetext{
${ }^{65}$ Ibid., pp. 325-6, 329, 333.

${ }^{66}$ Ibid., p. 336.

${ }^{67}$ George Shelley was responsible for the 11 th to 17 th editions, appearing from 1704 to 1740 ; James Dodson had a hand in preparing the 18th and 19th editions for the press in 1751 and 1760 respectively.
}

\footnotetext{
${ }^{68}$ Thomas Willsford, Willsfords arithmetick, naturall, and artificiall: or, decimalls. Containing the science of numbers.... Made compendious and facile for all ingenious capacities, viz: merchants, citizens, sea-men, accomptants, \&c., London, printed by J G for Nath. Brooke, 1656 (Wing W2874).

${ }^{69}$ Ibid., p. 250; S5v.
} 


\section{Alligation Alternate and the Composition of Medicines}

question or group of questions. The questions he propounds allowed the student to create compounds of a given quality, to determine the quality of compounds whose ingredients are known, or to increase or diminish the quality of any known compound by the addition or subtraction of another known compound. Finally, Willsford offered a "generall Rule", being both an expression of purpose and a disclaimer concerning the inclusion of medical subject matter in a popular text:

In all Rules of Alligation: in this last I doe not question the wise Children of Asculapius, nor the learned Disciples of Galen or Hippocrates, or presume to teach their expert Apothecaries any Rules, but to give an insight of theirs to please some, and assist others, who have more Practice than Theorie, and lesse Art than Experience. ${ }^{70}$

Although Willsford's fine Arithmetick was not reprinted, the author went on to edit a later edition of Record's Ground of arts (1662), carrying on the work of John Dee, John Mellis, and Robert Hartwell. Willsford claimed to correct more than 1000 errors which had crept into that work, but did not compose any new content. ${ }^{71}$

Willsford's connection with Record brings us full circle, for the innovations of the $1650 \mathrm{~s}$ do not seem to carry on after the Restoration. After the 1650 s, the only arithmetical texts I have found which contained chapters on the composition of medicines were later editions of the Moore and Wingate/Kersey arithmetics, and these chapters tended to be reprinted without change. (A very late exception was Benjamin Donn's Mathematical essays, editions of which appeared in 1758, 1764 and 1769, which I will discuss at the conclusion of this article.) Other arithmetics might include examples that feature "druggists"-for example, Hodder's Arithmetick ${ }^{72}$ (1661; third edition, 1664)—but without proofs or chapters on the composition of medicines. The title-page of John Newton's The art of natural arithmetick (1671) says that in it, "the multiplication and division of numbers of several denominations, and the rule of alligation are more fully explained, than in any treatise of this nature as yet extant in the English tongue". ${ }^{73}$ But Newton's textbook was specifically intended for children, not for adult merchants or (potentially) apothecaries; its new "explanation" of alligation was actually very difficult to follow; and the questions Newton propounded had nothing to do with medicine. Newton did praise Wingate, especially the second edition of 1650, "that though by reason of the several Phantasies of several men, something may be altered, there is but little that can be amended; but the bulk and price is such, that I fear but few parents will be willing to be at the charge of it, especially for such striplings, as I would have instructed in this Science". ${ }^{74}$

\footnotetext{
${ }^{70}$ Ibid., p. 261; T3.

${ }^{71}$ Robert Record, Records arithmetick: or, The ground of arts; teaching the perfect work and practice of arithmetick, London, printed by James Flesher, and are to be sold by Joseph Crawford, 1662 (Wing R646). See Willsford's postscript 'To every young Arithmetician, or Practitioner in numbers, who shall peruse these Bookes', pp. 534-6.

${ }^{72}$ James Hodder, Hodder's arithmetick, London, 1661, 3rd ed. 1664.

${ }^{73} \mathrm{John}$ Newton, The art of natural arithmetick, in whole numbers and fractions vulgar and decimal, in a plain and easie method suteable to the capacity of
}

children, for whom it is chiefly intended. In which the multiplication and division of numbers of several denominations, and the rule of alligation are more fully explained, than in any treatise of this nature as yet extant in the English tongue, London, printed by E[van] T[yler] and R[alph] H[olt] and are to be sold by Rob Walton, 1671 (Wing N1051B). Full title information from ESTCr225478.

${ }^{74}$ Newton's arithmetic book was republished after his death as The compleat arithmetician: or, The whole art of arithmetick, vulgar and decimal in a plain and easie method, suitable to the meanest capacity, in which the multiplication and division of numbers of several 


\section{Alvan Bregman}

\section{William Salmon's Synopsis Medicinx (1671)}

We have noted that the application of alligation to the composition of medicines presupposed a humoral theory of health, disease and medical remedy. After the Restoration, however, and with the resuscitation of the Royal College of Physicians and the founding of the Royal Society, learned medicine continued to move away from this theoretical foundation. Popular medicine, however, lagged behind in this matter. In 1671, the prolific medical popularizer and astrologer, William Salmon, published the first edition of his Synopsis medicina, or A compendium of astrological, Galenical, \& chymical physick. ${ }^{75}$ This encyclopaedic work was made up of three volumes, on diagnosis, prognosis, and therapeutics, respectively. In his discussion of therapeutics, the truly practical arm of medicine, Salmon was quite thoroughly astrological and Galenic in outlook. For example, he indicated which plants were governed by which planets, because this was important not only in their use, but in knowing how and when they should be gathered, and he insisted on the proper timing of treatments, also according to the planets. He gave considerable attention to the humours, before turning, in chapter 33 of the third volume, to the actual preparation of medicines. 'Of the Mathematical Composition of Medicines' assumed that the reader already had a knowledge of alligation alternate, and in this chapter Salmon described five applications of the operation, viz:

I. To make a Medicine proposed in any degree of quality whatsoever.

II. To find out the exact temperament of any Medicine.

III. To augment and dimish $[$ sic $]$ the quality of a Medicine, to any degree proposed.

IV. To augment or diminish in quantity any Medicine, keeping its first proportion.

V. To find what quantity of any Ingredient, is contained in any part of a Composition. ${ }^{76}$

Like Kersey, Salmon provided examples for and discussed the applications which involve "qualities", and gave only cursory treatment to quantitative applications of alligation. (Salmon devoted only one sentence each to operations IV and V.) Salmon is an equivocal figure: on the one hand he was a self-promoting astrologer and on the other a successor of Nicholas Culpeper, in that he translated and popularized both esoteric and necessary texts, from the works of Roger Bacon to the Pharmacopoeia Londonensis and the works of Thomas Sydenham. In 1693 Salmon published The compleat English physician; or, The druggist's shop opened, ${ }^{77}$ dedicated to Queen Mary, which contained over a thousand pages of entries on herbs, stones and chemicals and their (supposed) medicinal

denominations, and the rule of alligation are more fully explained than in any treatise of this nature, yet extant, London, printed for John Taylor and Christopher Browne, 1691 (Wing N1054). The quotation is from 'The Epistle to the Reader', A6v. At my request, Jennifer Schaffner, Reference Librarian at the William Andrews Clark Memorial Library, UCLA, kindly examined the text of the 1671 edition and found it to be identical to that quoted (private communication).

${ }^{75}$ William Salmon, Synopsis medicinae, or A compendium of astrological, Galenical, \& chymical physick. Philosophically deduced from the principles of
Hermes and Hippocrates. In three books. The first, laying down signs and rules how the disease may be known. The second, how to judge whether it be curable or not, or may end in life or death. The third, shewing the way of curing according to the precepts of Galen and Paracelsus, London, printed by W Godbid, for Richard Jones, 1671 (Wing S454).

${ }^{76}$ Ibid., pp. 497, 499, 501, 502.

${ }^{77}$ William Salmon, Seplasium. The compleat English physician; or, The druggist's shop opened. Explicating all the particulars of which medicines at this day are composed and made. Shewing their various names and natures, London, printed for 


\title{
Alligation Alternate and the Composition of Medicines
}

uses. However, he did not repeat his instructions on the mathematical composition of medicines, and his chapter on the mathematical composition of medicines remains an outlier in medical literature.

\begin{abstract}
Aftermath
It is possible to see the outburst of chapters on the composition of medicine in the $1650 \mathrm{~s}$ as part of the general explosion of interest in science and reform in the Interregnum. As Charles Webster has explained, "a great flood of medical literature ... appeared between 1650 and 1660, produced in an atmosphere charged with enthusiasm for every aspect of medical speculation, which was given ample room for expression with the collapse of censorship and the liberation of London medicine from the authority of the College of Physicians." 78 Moreover, the 1650 s was a period when Galenism was under attack by reformers, especially those who favoured a more scientific approach, based on chemistry and anatomy. This led to controversial exchanges about the university curriculum, including the medical curriculum. Examples include Noah Biggs, Mataeotechnia medicinae praxeos: The vanity of the craft of physick (1651; Wing, B2888) and John Webster, Academiarum examen (1654; Wing W1209). ${ }^{79}$ Webster was answered by Seth Ward, the Bishop of Salisbury, in a pamphlet called Vindiciae academiarum (1654; Wing W832). ${ }^{80}$ Ward defended the status quo, asserting that "The practice of Physick hath been bottomed upon experience and observation", that "the Colledge of Physitians at London is the glory of this Nation, and indeed of Europe, for their Learning and felicity, in the cures of desperate Ulcers and diseases, even of the Cancer ..."; and finally, that rather than being a prison in which men are enchained, "that Galenicall Physick had served to make men loose, and not to be a prison to them". ${ }^{81}$

Related to the controversy about the medical curriculum was the ongoing struggle in the seventeenth century between the physicians and the apothecaries, part of which resulted in repeated suggestions that physicians should be able to make and sell their own medicines. The seventeenth century also saw the beginnings of a shift away from Galenic medicine. The followers of Paracelsus and Van Helmont espoused a different theoretical explanation of disease, which they proposed to cure with largely chemical preparations. An attempt around mid-century to form a "Society of Chymical Physitians", which would have brought together numerous unlicensed practitioners, including apothecaries and surgeons, was supported by the Helmontians. ${ }^{82}$ New anatomical studies, most notably those made by Harvey, also forced a review of Galenic practice.

Nevertheless, the argument about the composition of medicines was persistent. Most physicians did not make their own medicines, but relied on apothecaries for this purpose.
\end{abstract}

Matthew Gilliflower and George Sawbridge, 1693 (Wing S452).

${ }^{78}$ Charles Webster, The great instauration: science, medicine and reform, 1626-1660, London, Duckworth, 1975, p. 265.

${ }^{79}$ See ibid., pp. 191 and 198-202.

${ }^{80}$ Webster's and Ward's pamphlets are reproduced with an extensive introduction in Allen G Debus,
Science and education in the seventeenth century:

The Webster-Ward debate, London, Macdonald, 1970.

See also Taylor, op. cit, note 1 above, p. 97.

${ }^{81}$ John Wilkins and Seth Ward, Vindiciae academiarum, Oxford, printed by Leonard Lichfield . . . for Thomas Robinson, 1654, pp. 35-6, 47; in Debus, ibid., pp. 229-30, 241.

${ }^{82}$ Webster, op. cit., note 78, above, p. 307. 


\section{Alvan Bregman}

Throughout the century, learned physicians accused the apothecaries of diagnosing diseases and prescribing treatments, activities outside their charter. The College of Physicians was on the verge of gaining control of the apothecaries when the Revolution occurred. During that time, the practice of medicine was considerably democratized, and it is possible to see the practical instruction which appeared in the $1650 \mathrm{~s}$ on the mixture of compounds as part of this movement.

After the Restoration, the College of Physicians revived and numerous texts were published urging reform against apothecaries who practised medicine. In 1665 the case was ably put, by “T.M.", apparently a member of Parliament, in A letter concerning the present state of physick, and the regulation of the practice of it in this kingdom written to a doctor here in London (Wing M81C) ${ }^{83}$ A full-blown pamphlet war broke out in 1669 when Christopher Merrett published his A short view of the frauds, and abuses committed by apothecaries ... and of the only remedy therof by physicians making their own medicines (Wing M1843), in which Merrett repeated a great number of arguments found in T.M.'s more measured pamphlet. Merrett was the librarian of the College of Physicians before the Fire and also a freeman of the Society of Apothecaries, but he wrote his pamphlets from outside the medical establishment, as a member of the Royal Society. The apothecaries issued their own responses. ${ }^{84}$

T.M. and Merrett both indicate the benefits of physicians making their own medicines, and note the importance of being able to mix compounds properly. None of the pamphlets, however, specifically outline the methods for doing so. Perhaps Moore, Kersey and Willsford were sensitive to this undercurrent and sought to provide information to a waiting market. Regardless of the extent of the influence of their texts, their projects constitute a pre-modern attempt to apply mathematics to medicine.

The chapters on the composition of medicines that we have been examining seem to straddle these controversies. As E G R Taylor says with reference to the period 1650-60, "it is difficult to estimate exactly where applied mathematics stood in the intellectual life of the day". ${ }^{85}$ Still, we can see that our arithmeticians were attempting to bring into the open practical applications of mathematics for the good of the commonwealth and its newly enfranchised citizens. The Galenic basis for the composition of medicines betrays a certain conservatism on their parts, but at least the methods were available for physicians, apothecaries or even members of the general educated public to deal better with compound remedies. That they did not make more of these methods as the century progressed is simply a sign that the mathematical applications of mathematics to medicine would to all intents and purposes remain part of the mysteries of practice, as they have done to this day.

We conclude by looking at a late link in this chain. In 1758, Benjamin Donn (or Donne) published the first edition of his Mathematical essays, being essays on vulgar and decimal arithmetick. ${ }^{86}$ Donn, of Bideford in Devon, advertised himself as a "Teacher of the

\footnotetext{
${ }^{83}$ See Sir George Clark, A history of the Royal College of Physicians of London, Oxford, Clarendon Press for the Royal College of Physicians, 1964, vol. 1, p. 308 and note 3 .

${ }^{84}$ For a discussion of the debate and a list of the relevant pamphlets, see Harold J Cook, 'Henry Stubbe and the virtuosi-physicians', in Roger French and
} 


\section{Alligation Alternate and the Composition of Medicines}

Mathematics, and Natural Philosophy, on Newtonian Principles". The theme of Donn's 'General Preface' has much in common with Dee's Mathematical praface, for in it, Donn outlines the innumerable applications of mathematics to all human endeavours. One of the principal applications, says Donn, is to "the Study of Medicine, and other Arts relating thereto":

Before the Discovery of true Philosophy, the Art of Chymistry and Medicine were made up of unintelligible Terms, false Hypotheses, and Metaphysical Jargon: Hence the more a Person read, the more likely he was to be misled and confounded, unless he confined himself to read barely the experimental Knowledge of a few celebrated Names. But now, since the great Discoveries of the most learned NEWTON, we are enabled to enquire into the Principles of Chymistry and Medicine in a rational Manner, from the Knowledge of the Laws of Motion and Action of Bodies.... For, since it is confirmed by the modern Observations and Improvements in Anatomy, "That the Animal Body is a pure Machine, and that all its Operations and Phænomena, with the several Changes which happen to it, are the necessary Result of its Organization and Structure;" it follows, that such as are acquainted with Mathematical Philosophy are best able to study the Animal Oeconomy, and consequently, cateris paribus, are better qualified for curing Diseases. ${ }^{87}$

Donn's chapter 'Of Alligation Alternate' explicates the traditional arithmetical technique we have examined, but points out that the problems with which it deals "will be much better solved, when we treat of unlimited Questions in Algebra: For, whereas the common Methods of working Alligation Alternate, \&c. find many Times only a few Answers, and those frequently in broken or fractional Numbers, Algebra discovers all the possible Answers in whole Numbers". In reading Donn's next chapter, 'Of Compounding Medicines', we can see that he is not at all concerned with the determination of medicinal "quality" as were the arithmeticians of the mid-seventeenth century. The problem he proposes to solve with alligation alternate is "to augment or diminish a Medicine in Quantity, but, at the same Time, to retain the Proportions which the several Simples of which it is compounded, have to each other". ${ }^{88}$ In fact, Donn speaks out against the investigations of "Quality", and in doing so passes over the Galenic sense of the term. Donn takes the notions of Heat and Cold in a literal and physical sense. The mixture of two differentially "cold" simples need not produce an intermediate degree of cold, since, as "Dr. DeSAGULIER, and others, have found by Experiments, that two cold Things, viz. Oil of Tarter per Deliquium, poured on Oil of Vitriol, will produce Heat, by causing the compound to boil, fume, \&". And so we come to the final point:

We have only now to add, that neither does the Efficacy of most Medicines depend so much on the different Degrees of Heat and Cold, as on some other Properties peculiar to them; and that our Design in this Scholium was only to produce sufficient Reason for omitting what some ingenious Authors have thought they have usefully inserted, and to shew that such Questions do not admit of an Arithmetical solution. ${ }^{89}$

London, printed for W Johnston, P Davey and B Law, 1758 (ESTCt96887).

${ }^{87}$ Ibid., p. Xvii. Donn is quoting the preface of Thomas Morgan's Philosophical principles of medicine, in three parts (1725; enlarged ed., 1730). He then goes on to quote at length from such authors as
Hermann Boerhaave (d. 1738), James Keill (d. 1719), and Richard Mead (d. 1754). Indeed, the majority of Donn's preface is little more than a pastiche of lengthy quotations from these and other authors.

${ }^{88}$ Ibid., p. 204.

${ }^{89}$ Ibid., p. 206. 


\section{Alvan Bregman}

We might apply this to the mathematical applications to medicine found in arithmetics by saying that they no longer belong in the elementary, or "natural" sections but in the more learned, or "artificial" explanations of the subject. While there were other vestigial and completely derivative arithmetical presentations concerning the composition of medicines in the eighteenth century, ${ }^{90}$ it seems that the usefulness of alligation alternate as a specialized mathematical technique applicable to the composition of medicine had come to a natural end.

${ }^{90}$ For example, Daniel Fenning, in The schoolmaster's most useful companion, and scholar's best instructor in the knowledge of arithmetic, London, printed for the author and sold by S Crowder, 1765 (ESTCn36277), has a brief section on the composition of medicines (pp. 132-4) which explains the Galenic qualities in bodies in an entirely conventional manner.
Fenning dedicates his work to "the school-masters of Great Britain and Ireland, and to other teachers of youth in arithmetic" (p. iii). Set up as a dialog between a "Tutor or Master and his young Pupil or Scholar", this work certainly does not address the adult audience of practitioners as did the arithmetic writers of the 1650s. 